servations on the natural course of cervical intraepithelial neoplasia in relation to human papillomavirus infection.

This research was supported by a grant from the Cancer Research Campaign. We acknowledge the help and guidance of Mr D M Luesley, Mr J A Jordan, Dr C A Meanwell, and Professor E G Knox and thank the Brook Advisory Centre for its cooperation, Dr J Fox for synthesising the oligonucleotides, and Miss D Williams for typing the manuscript. cancer related to current searches for transmissible agents. Cancer Res 1973;33:1353-67

2 Cook GA, Draper GJ. Trends in cervical cancer and carcinoma in situ in Great Britain. Br f Cancer 1984;50:367-75.

3 Reid R, Stanhope R, Herschman VR, et al. Genital warts and cervical cancer. Cancer 1982;50:377-87.

+ Walker PG. Singer A, Dyson JL, Shah KV, To A, Coleman DV. The prevalance of human papillomavirus antigen in patients with cervical prevalance of human papillomavirus antigen in paic

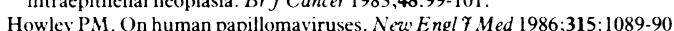

6 De Villiers EM, Gissman L, Zur Hausen H. Molecular cloning of viral DNA from human genital warts. $\mathcal{f}$ Virol 1981;40:932-5.

Gissman L, Zur Hausen H. Partial characterisation of viral DNA from human genital warts (condylomata acuminata). Int f Cancer 1980;29:143-6.

8 Gissman L, Wolnik L, Ikenberg H, Koldorsky V, Schnurch HG, Zur Hausen H. Human papillomavirus types 6 and 11 DNA sequences in genital and laryngeal papillomas and in some cervical cancers. Proc Natl Acad Sci USA 1983;80:560-3.

9 Durst M, Gissman L, Ikenberg H, Zur Hausen H. A papillomavirus DNA from a cervical cancer and its prevalence in cancer biopsy samples from different geographic regions. Proc Natl Acad Sci USA 1983;80:3812-5.

10 Boshart M, Gissman L, Ikenberg H, Kleinheinz A, Schuerlen W, Zur Hausen $\mathrm{H}$. A new type of papillomavirus DNA, its presence in genital cancer H. A new type of papillomavirus DNA, its presence in genital cancer
biopsies and in cell lines derived from cervical cancer. EMBO f 1984;3: biopsies

11 Lorincz. AT, Lancaster WD, Temple GF. Cloning and characterisation of the DNA of a new papillomavirus from a woman with dysplasia of the uterine cervix. F l'irol 1986;58:225-9.

12 Beaudenon S, Kremsdorf D, Croissant O, Jablonska S, Wash-Hobson S, Orth GA. A novel type of papillomavirus associated with genital neoplasias. Nature 1986;321:246-9.
13 Lorincz. AT, Quinn AP, Lancaster WD, Temple GF. A new type of papillomavirus associated with cancer of the uterine cervix. V'irology 1987; 159:187-90.

14 McCance DJ. Human papillomavirus and cancer. Biochim Biophys Acte 1986;283:205-9.

15 Schneider A, Kraus H, Schuhmann R, Gissman L. Papillomavirus infection of the lower genital tract: detection of viral DNA in gynaecological swabs. $\operatorname{Int} \mathcal{F}$ (985:35:443-8.

16 Wickenden C, Steele A, Malcolm ADB, Coleman DV. Screening for wart virus infection in normal and abnormal cervices by DNA hybridisation of cervical crapes. Lancet 1987; i:65-7.

17 Toon PG, Arrand JR, Wilson LP, Sharp DS. Human papillomavirus infection of the uterine cervix of women without cytological signs of neoplasia. Br.Med $f$ $1986 ; 293: 1261-4$

18 Cox MF, Meanwell CA, Maitland NJ, Scully C, Blackledge G, Jordan JA Human papillomavirus type 16 homologous DNA in normal human ectocervix. Lancet 1986;ii:157-8.

19 Meanwell CA, Cox MF, Blackledge G, Maitland NJ. HPV 16 DNA in norma and malignant cervical epithelium: implications for the aetiology and hebaviour of cervical neoplasia. Lancet 1987; : $: 703-7$.

20 Gergely L. Czegledy J, Hernady $Z$. Human papillomavirus frequency in normal cervical tissue, Lancet 1987;ii:513.

21 De Villiers EM, Wagner D, Schneider A, et al. Human papillomavirus infections in women with and without abnormal cervical cytology. Lance 1987;ii: 703-5.

22 Munuz N, Bosch X, Kaldor JM. Does human papillomavirus cause cervical cancer? The state of the epidemiological evidence. Brf Cancer 1988;57:1-5.

23 Saiki RK, Gelfand DH, Stoffel S, et al. Primer-directed enzymatic amplificatio of DNA with a thermostable DNA polymerase. Science 1988;239:487-91.

24 Ferenczy A. Cervical intraepithelial neoplasias. In: Blausen A, ed. Pathology of the female genital tract. New York: Springer-Verlag, 1977:156-77.

25 International Agency for Research on Cancer. Human papillomavirus and cervical cancer. Lancet 1988;i:756-7 (Conference report).

26 Lo Y-MD, Mehal WZ, Fleming KA. False-positive results and the polymerase chain reaction. Lancet 1988 ;ii:679.

27 Wagner D, Ikenberg H, Doehm N, Gissman L. Identification of human papillomavirus in cervical swabs by deoxyribonucleic acid in situ hybridization Obset Gynecol 1984:64:767-72.

28 Schneider A Kraus $\mathrm{H}$, Schuhmann R, Gissman L. Papillomavirus infection of the lower genital tract: detection of viral DNA in gynaecological swabs. Int $\mathcal{7}$ Cancer 1985;35:443-8.

29 Crum CP, Nagai N, Levine R, Silverstein S. In situ hybridization analysis of HPV 16 DNA sequences in early cervical neoplasia. Am f Pathol 1986;123 $174-82$.

(Accepted 27 October 1988)

\title{
Prevalence of diabetes in a predominantly Asian community: preliminary findings of the Coventry diabetes study
}

\author{
D Simmons, D R R Williams, M J Powell
}

\begin{abstract}
To assess the prevalence of both diagnosed and undiagnosed diabetes mellitus in an area of predominantly Asian population the Coventry diabetes study is carrying out house to house screening for diabetes in people aged 20 and over in Foleshill, Coventry. In the first five of 12 areas to be studied 2130 of 2283 Asian $(93.3 \%)$ and 1242 of 1710 white subjects $(72 \cdot 6 \%)$ aged $20-79$ agreed to be screened. The prevalence of diabetes adjusted to 1987 demographic estimates was $11.2 \%$ in Asian men and $8.9 \%$ in Asian women whereas it was $2.8 \%$ in white men and $4.3 \%$ in white women. The excess of diabetes in Asian subjects was predominantly of non-insulindependent diabetes, and no significant differences in body mass were found to account for the higher prevalence.
\end{abstract}

Diabetes had not been diagnosed previously in at least $26 \%$ of the white and $30 \%$ of the Asian diabetics screened, and it is estimated that in this community the condition remains undiagnosed in $42 \%$ of white and $40 \%$ of Asian diabetics.

\section{Introduction}

The Southall diabetes study showed that the prevalence of known diabetes in Asian people was four times that in white people, 'but the proportion of diabetics in whom the condition remains undiagnosed among Asians is unknown and may differ from that among whites. To investigate this further the Coventry diabetes study was established to screen the adults in Foleshill, Coventry, an area with a predominantly Asian population. We report the preliminary findings.

\section{Methods}

The electoral ward of Foleshill has a population of 18500 , of whom 11000 are aged 20 and over. It has traditionally been the area of initial immigration into Coventry: earlier this century from the north of England and from Ireland, then from eastern Europe, and more recently by Asians from either the Indian subcontinent or Africa. More than a quarter of the population is unemployed, and over 2500 residents leave and enter Foleshill each year. It is one of the most underprivileged wards in England and Wales. ${ }^{2}$

For the survey Foleshill was divided into 12 areas, and our results are of the first five areas screened. Al people resident in the area for more than four months each year and aged 20 and over were included. The survey was given extensive publicity in the local press, on radio and television, and by the display of posters in prominent places. Residents were notified by multilanguage leaflets distributed the day before the visit of the reasons for the survey and the expected arrival time of the team. They were visited at home by two of 15 fieldworkers who had been recruited from the local population; half of the fieldworkers could speak an Asian language. The information obtained from the 
people interviewed included age; whether they were known to be diabetic or not; religion; what they considered to be their ethnic identity; mother tongue; their place of birth and that of their parents and grandparents; and how long ago any food or drink had been taken. Height and weight in light clothes were measured, and a casual capillary whole blood sample was taken from the finger into a fluoride-nitriteheparin capillary tube (finger prick test).

The sample was refrigerated within two hours and analysed with a glucose oxidase glucose analyser (GM5, Analox) within 12 hours. If the blood glucose concentration was $\geqslant 6.0 \mathrm{mmol} / 1$ within two hours after eating or if it was $>4.4 \mathrm{mmol} / \mathrm{l}$ two hours or more after eating the subject was invited to take a modified oral glucose tolerance test. To assess the sensitivity of the screening values $10 \%$ of subjects with negative test results were also invited to take the oral glucose tolerance test, although this was done only after the first four areas had been screened. All oral glucose tolerance tests were started between 930 and 1130 am after an overnight fast of at least 10 hours. Two measurements of glucose concentration in capillary whole blood were taken, one fasting and one two hours after ingestion of $388 \mathrm{ml}$ Lucozade (Beechams), equivalent to $75 \mathrm{~g}$ anhydrous glucose. The diagnosis of diabetes or impaired glucose tolerance followed the World Health Organisation's recommendations: blood glucose concentration two hours after glucose loading $\geqslant 11.1 \mathrm{mmol} / \mathrm{l}$ indicated diabetes; fasting blood glucose concentration $<6.7 \mathrm{mmol} / 1$ and two hour glucose concentration $\geqslant 7.8 \mathrm{mmol} / \mathrm{l}$ but $<11.0 \mathrm{mmol} / \mathrm{l}$ indicated impaired glucose tolerance. ${ }^{3}$ Diabetes that had been diagnosed previously was confirmed by a casual blood glucose concentration $>8.0 \mathrm{mmol} / \mathrm{l}$, by the patient receiving drug treatment, or by verification from the general practitioner.
For houses where residents refused to be screened or were absent basic data about the occupants were entered from the electoral register and family practitioner lists. Patients with previously diagnosed diabetes who were not seen were identified from general practitioner records by the practice receptionist. No data were available for eight addresses.

Data were entered on an IBM 3081 mainframe computer and computed with the statistical package for the social sciences (SPSS X). ${ }^{4}$ Approval for the study was obtained from both the local ethical committee and the local medical committee.

\section{Results}

Of the 4673 residents in the area surveyed 2283 Asian and 1710 white residents were aged 20-80 and thus were eligible for inclusion in the study. Of the Asians, $1606(70 \cdot 4 \%)$ were Punjabi. In all, 1242 white subjects $(72 \cdot 6 \%)$ and 2130 Asians $(93 \cdot 3 \%)$ agreed to be screened. Of these, $280(22 \cdot 5 \%)$ white subjects and $438(20.6 \%)$ Asians were invited to have an oral glucose tolerance test; $161(57 \cdot 5 \%)$ and $281(64 \cdot 2 \%)$, respectively, attended. Table I shows the response rate, number of patients in whom diabetes had previously been detected and was newly diagnosed, proportion of those in whom diabetes was newly diagnosed who had a fasting blood glucose concentration $\geqslant 6.7 \mathrm{mmol} / \mathrm{l}$, prevalence of diabetes and impaired glucose tolerance, and mean body mass index in the Asian and white subjects.

Overall unadjusted prevalence was calculated by adding the crude prevalence of known diabetes in the total population to the crude prevalence of previously undiagnosed diabetes in the sample who had been seen. Overall unadjusted prevalence was $4 \cdot 0 \%$ in white men, $4 \cdot 6 \%$ in white women, $8 \cdot 8 \%$ in Asian men, and

TABLE I - Prevalence of diabetes in white and Asian residents of Foleshill, Coventry

\begin{tabular}{|c|c|c|c|c|c|c|c|c|c|c|c|c|}
\hline & \multicolumn{6}{|c|}{ Men } & \multicolumn{6}{|c|}{ Women } \\
\hline & \multicolumn{2}{|c|}{ Aged 20-39 } & \multicolumn{2}{|c|}{ Aged 40-59 } & \multicolumn{2}{|c|}{ Aged 60-79 } & \multicolumn{2}{|c|}{ Aged 20-39 } & \multicolumn{2}{|c|}{ Aged 40-59 } & \multicolumn{2}{|c|}{ Aged 60-79 } \\
\hline & $\begin{array}{c}\text { White } \\
(\mathbf{n}=325)\end{array}$ & $\underset{(\mathbf{n}=582)}{\text { Asian }}$ & $\begin{array}{l}\text { White } \\
(\mathrm{n}=225)\end{array}$ & $\begin{array}{c}\text { Asian } \\
(\mathrm{n}=366)\end{array}$ & $\begin{array}{c}\text { White } \\
(\mathbf{n}=281)\end{array}$ & $\begin{array}{c}\text { Asian } \\
(\mathbf{n}=139)\end{array}$ & $\begin{array}{l}\text { White } \\
(\mathbf{n}=313)\end{array}$ & $\begin{array}{c}\text { Asian } \\
(n=694)\end{array}$ & $\begin{array}{l}\text { White } \\
(\mathrm{n}=238)\end{array}$ & $\begin{array}{c}\text { Asian } \\
(\mathbf{n}=390)\end{array}$ & $\begin{array}{l}\text { White } \\
(\mathrm{n}=328)\end{array}$ & $\begin{array}{c}\text { Asian } \\
(\mathbf{n}=112)\end{array}$ \\
\hline $\begin{array}{l}\text { No (\%) known to have diabetes } \\
95 \% \text { Confidence interval for }\end{array}$ & $2(0 \cdot 6)$ & $9(1.5)$ & $6(2 \cdot 7)$ & $30(8 \cdot 2)$ & $13(4 \cdot 6)$ & $24(17 \cdot 3)$ & $1(0 \cdot 3)$ & $8(1 \cdot 2)$ & $9(3 \cdot 8)$ & $23(5 \cdot 9)$ & $14(4 \cdot 3)$ & $16(14 \cdot 3)$ \\
\hline difference in proportions $(\%)$ & \multicolumn{2}{|c|}{0.0 to 2.2} & \multicolumn{2}{|c|}{$2 \cdot 0$ to $9 \cdot 0$} & \multicolumn{2}{|c|}{6.0 to 19} & \multicolumn{2}{|c|}{0.0 to 1.9} & \multicolumn{2}{|c|}{0.0 to 5.5} & \multicolumn{2}{|c|}{$2 \cdot 4$ to $17 \cdot 6$} \\
\hline $\begin{array}{l}\text { No }(\%) \text { given finger prick test } \\
\text { No }(\%) \text { newly diagnosed as diabetic }\end{array}$ & $\begin{array}{c}250(76 \cdot 9) \\
0\end{array}$ & $\begin{array}{r}529(90 \cdot 9) \\
6(1 \cdot 1)\end{array}$ & $\begin{array}{r}155(68 \cdot 9) \\
1(0 \cdot 6)\end{array}$ & $\begin{array}{r}316(86 \cdot 3) \\
14(4 \cdot 4)\end{array}$ & $\begin{array}{r}173(61 \cdot 6) \\
3(1 \cdot 7)\end{array}$ & $\begin{array}{r}111(79 \cdot 9) \\
9(8 \cdot 1)\end{array}$ & $\begin{array}{l}235(75 \cdot 0) \\
0\end{array}$ & $\begin{array}{r}621(89 \cdot 5) \\
2(0 \cdot 3)\end{array}$ & $\begin{array}{r}173(72 \cdot 7) \\
\quad 4(2 \cdot 3)\end{array}$ & $\begin{array}{r}353(90 \cdot 5) \\
12(3 \cdot 4)\end{array}$ & $\begin{array}{r}211(64 \cdot 3) \\
8(3.8)\end{array}$ & $\begin{array}{r}90(80 \cdot 4) \\
5(5 \cdot 6)\end{array}$ \\
\hline $\begin{array}{l}95 \% \text { Confidence interval for } \\
\text { difference in proportions (\%) }\end{array}$ & \multicolumn{2}{|c|}{$0 \cdot 2$ to $2 \cdot 0$} & \multicolumn{2}{|c|}{$1 \cdot 2$ to $6 \cdot 4$} & \multicolumn{2}{|c|}{1.0 to $11 \cdot 8$} & \multicolumn{2}{|c|}{$0 \cdot 0$ to $0 \cdot 7$} & \multicolumn{2}{|c|}{$0 \cdot 0$ to $3 \cdot 4$} & \multicolumn{2}{|c|}{$0 \cdot 0$ to $7 \cdot 3$} \\
\hline $\begin{array}{l}\text { No }(\%) \text { with fasting blood glucose } \\
\geqslant 6.7 \mathrm{mmol} / 1\end{array}$ & 0 & $3(0 \cdot 6)$ & 0 & $9(2 \cdot 8)$ & $1(0 \cdot 6)$ & $6(5 \cdot 4)$ & 0 & $1(0 \cdot 2)$ & $3(1 \cdot 7)$ & $7(2 \cdot 0)$ & $3(1 \cdot 4)$ & $2(2 \cdot 2)$ \\
\hline $\begin{array}{l}\text { No (\%) with impaired glucose } \\
\text { tolerancet }\end{array}$ & $3(1 \cdot 2)$ & $1(0 \cdot 2)$ & $4(2 \cdot 6)$ & $6(1.9)$ & $9(5 \cdot 2)$ & $5(4 \cdot 5)$ & $1(0 \cdot 4)$ & $4(0 \cdot 6)$ & $2(1 \cdot 2)$ & $11(3 \cdot 1)$ & $11(5 \cdot 2)$ & $3(3 \cdot 3)$ \\
\hline $\begin{array}{c}95 \% \text { Confidence interval for } \\
\text { difference in proportions }(\%) \\
\text { Mean (SD) body mass index }\left(\mathrm{kg} / \mathrm{m}^{2}\right) \ddagger\end{array}$ & \multicolumn{2}{|c|}{0.0 to 2.4} & \multicolumn{2}{|c|}{0.0 to 3.6} & 0.0 to 5.8 & $\begin{array}{l}5.8 \\
26 \cdot 3(3.9)\end{array}$ & \multicolumn{2}{|c|}{0.0 to 1.2} & \multicolumn{2}{|c|}{$0 \cdot 0$ to +.3} & \multicolumn{2}{|c|}{$\begin{array}{c}0 \cdot 0 \text { to } 6 \cdot 7 \\
27 \cdot 1(5 \cdot 6) \quad 28 \cdot 2(5 \cdot 5)\end{array}$} \\
\hline
\end{tabular}

$\star$ Blood glucose concentration $\geqslant 11 \cdot 1 \mathrm{mmol} / 1$ two hours after glucose loading.

†Blood glucose concentration $<6.7 \mathrm{mmol} / \mathrm{l}$ after fasting and $\geqslant 7.8 \mathrm{mmol} / \mathrm{l}$ but $<11.0 \mathrm{mmol} / \mathrm{l}$ two hours after glucose loading

$\ddagger$ Analysis of variance for white subjects $v$ Asians was non-significant in each age group.

TABLE II - Number (percentage) of new diagnoses of diabetes and impaired glucose tolerance on oral glucose tolerance testing according to blood glucose concentration on finger prick test

\begin{tabular}{|c|c|c|c|c|c|c|c|c|c|c|c|c|c|c|c|c|c|c|}
\hline & \multicolumn{9}{|c|}{ Men } & \multicolumn{9}{|c|}{ Women } \\
\hline & \multicolumn{2}{|c|}{$4.5-5.0 \mathrm{mmo} / \mathrm{l}$} & \multicolumn{2}{|c|}{$5 \cdot 1.8 \cdot 0 \mathrm{mmol} / 1$} & \multicolumn{2}{|c|}{$8 \cdot 1.11 \cdot 0 \mathrm{mmol} / 1$} & \multicolumn{2}{|c|}{$\geqslant 11.1 \mathrm{mmol} / 1$} & \multirow[b]{2}{*}{$\begin{array}{c}\text { Random } \\
(\mathbf{n}-93)\end{array}$} & \multicolumn{2}{|c|}{$4.5-5.0 \mathrm{mmol} / \mathrm{l}$} & \multicolumn{2}{|c|}{$5.1 .8 .0 \mathrm{mmol} / \mathrm{I}$} & \multicolumn{2}{|c|}{$8 \cdot 1.11 .0 \mathrm{mmol} / \mathrm{l}$} & \multicolumn{2}{|c|}{$\geqslant 11.1 \mathrm{mmol} / 1$} & \multirow[b]{2}{*}{$\begin{array}{l}\text { Random } \\
\mathrm{n}=129\end{array}$} \\
\hline & $\begin{array}{l}\text { White } \\
(\mathbf{n}=37)\end{array}$ & $\begin{array}{c}\text { Asian } \\
(\mathrm{n}=55)\end{array}$ & $\begin{array}{c}\text { White } \\
(\mathrm{n}=80)\end{array}$ & $\underset{(n=114)}{\text { Asian }}$ & $\begin{array}{c}\text { White } \\
(n=14)\end{array}$ & $\begin{array}{l}\text { Asian } \\
(\mathbf{n}=31)\end{array}$ & $\begin{array}{l}\text { White } \\
(\mathbf{n}=2)\end{array}$ & $\begin{array}{c}\text { Asian } \\
(\mathrm{n}=17)\end{array}$ & & $\begin{array}{l}\text { White } \\
(\mathrm{n}=30)\end{array}$ & $\begin{array}{l}\text { Asian } \\
(\mathrm{n}=57)\end{array}$ & $\begin{array}{l}\text { White } \\
(\mathrm{n}=85\end{array}$ & $\begin{array}{l}\text { Asian } \\
(\mathrm{n} \div 128)\end{array}$ & $\begin{array}{l}\text { White } \\
(\mathbf{n}=20)\end{array}$ & $\begin{array}{l}\text { Asian } \\
(\mathbf{n}=20)\end{array}$ & $\begin{array}{l}\text { White } \\
(\mathrm{n}=4)\end{array}$ & $\begin{array}{c}\text { Asian } \\
(n-8)\end{array}$ & \\
\hline \multirow{4}{*}{$\begin{array}{l}\text { Patients attending } \\
\text { Newly diagnosed as } \\
\text { diabetic } \\
\text { Newly diagnosed as } \\
\text { having impaired } \\
\text { glucose tolerance } \dagger \\
\text { Patients with diabetes } \\
\text { missed } \neq\end{array}$} & $14(38)$ & $22(40)$ & $50(63)$ & $77(68)$ & $11(79)$ & $22(71)$ & $1(50)$ & $12(71)$ & $47(51)$ & $9(30)$ & 3460 & $55(65)$ & $85(66)$ & 1260 & $17(85)$ & 375 & $7(88)$ & 8364 \\
\hline & 0 & 0 & $2(4)$ & $8(10)$ & 0 & $8(36)$ & $1(100)$ & $11(92)$ & 0 & 0 & 0 & $8(15)$ & 78 & $2(17)$ & $6(35)$ & 3100 & 6.86 & $2: 2$ \\
\hline & $3(21)$ & $1(5)$ & $8(16)$ & 5 (6) & $3(27)$ & $5(23)$ & 0 & 1 & 36 & 0 & $1(3)$ & $11(20)$ & $10 \div 12$ & $5(42:$ & $4(24)$ & 0 & $1(14$ & 78 \\
\hline & 0 & 0 & 1 (1) & $4(4)$ & 0 & $3(10)$ & $1(50)$ & $5(29)$ & & 0 & 0 & +5 & $3(2)$ & 15 & 15 & 125 & $1 / 13$ & \\
\hline
\end{tabular}

$\star$ Blood glucose concentration $\geqslant 11 \cdot 1 \mathrm{mmol} / \mathrm{t}$ two hours after glucose loading.

†Blood glucose concentration $<6.7 \mathrm{mmol} / \mathrm{l}$ after fasting and $\geqslant 7.8 \mathrm{mmol} / \mathrm{l}$ but $<11.0 \mathrm{mmol} / \mathrm{l}$ two hours after glucose loading.

tEstimated numbers. 
$5.7 \%$ in Asian women. After adjustment to 1987 demographic estimates ${ }^{5}$ by direct standardisation ${ }^{6}$ overall age specific prevalences for people aged 20-79 were $2.8 \%$ for white men, $4.3 \%$ for white women, $11 \cdot 2 \%$ for Asian men, and $8.9 \%$ for Asian women.

Table II shows the blood glucose concentrations of those invited for oral glucose tolerance tests and the proportions found to have diabetes or impaired glucose tolerance. From the first three areas screened none of the 79 people who had an initial blood glucose concentration of $4 \cdot 5-5 \cdot 0 \mathrm{mmol} / \mathrm{l}$ and attended for oral glucose tolerance tests had diabetes. Thus the concentration for referral for glucose tolerance testing was increased to $\geqslant 5.0 \mathrm{mmol} / \mathrm{l}$, which allowed $10 \%$ of those with negative results from the areas subsequently screened to be invited for oral glucose tolerance testing so that the sensitivity of the screening values could be assessed. Of the 222 people randomised to oral glucose tolerance testing, 130 attended, only two of whom were found to be diabetic.

Of 155 subjects with previously diagnosed diabetes, $13(29 \%)$ white and $14(13 \%)$ Asian patients were treated with insulin $\left(\chi^{2}=4.3, p<0.05\right)$, and $17(37 \%)$ white and $11(10 \%)$ Asian diabetics were managed by $\operatorname{hospital}\left(\chi^{2}=17 \cdot 6, \mathrm{p}<0 \cdot 001\right)$.

\section{Discussion}

This survey showed that the prevalence of diabetes was four times higher in Asian men than white men and twice as high in Asian women as in white women, even though a higher than expected prevalence was found in white subjects. An unadjusted prevalence ratio of $3: 2$ in Asian men to women has been shown in both the United Kingdom and India. ${ }^{17}$ Asian men and women aged over 60 have similar prevalences, which may be due to men dying early from cardiovascular causes. The prevalence of diabetes has been found to be almost equal in white men and women."

No difference in body mass index was found between Asian and white subjects. Although fat distribution and the relation between weight and height may be different in Asians, the body mass index is considered the best measure of obesity..$^{10}$ This lack of difference in body mass index between white and Asian subjects, the different sex ratio of diabetes in Asians, and the high number of Asians aged under 40 with non-insulin-dependent diabetes may indicate an extra aetiological factor in a proportion of the population that leads to failure of $\beta$ cells at an earlier age. This supports the hypothesis that non-insulin-dependent diabetes is a group of conditions rather than a single entity. ${ }^{\prime \prime}$

The higher than expected prevalence in the white residents of Foleshill is in keeping with the underprivilege of the area, a factor known to be associated with a higher prevalence of diabetes, ${ }^{12}$ partly owing to increased body mass. Indeed, the mean body mass of white residents of Foleshill was higher than that of white people in other areas for all age groups. ${ }^{13}$ The findings of the Oxford diabetes study suggested that the prevalence of diabetes in white people in the United Kingdom may be increasing, but we are unable to comment on this from our cross sectional study. The similar prevalence of impaired glucose tolerance in the white and Asian populations is equally notable. The data inevitably provide an underestimate of the prevalence in each group but should not introduce bias. One possibility, which is in keeping with the hypothesis of an extra aetiological factor among some Asians, is that impaired glucose tolerance may develop into diabetes more quickly among Asians.

Diabetes had not been diagnosed previously in at least one third of the Asian men and women and white women but in only a sixth of white men. A higher rate of diagnosis in men may account for their higher referral rate to the United Kingdom prospective diabetes study, ${ }^{14}$ possibly because the disease is more severe in men, ${ }^{15}$ men are more likely to be screened, or men tend to notice urinary symptoms. It was estimated in 1947 that half of all diabetes in the population was undiagnosed. ${ }^{16}$ Our study is the first population based screening to assess this since the Bedford study in $1962,{ }^{17}$ and the proportion of cases found by opportunistic case finding would be expected to have increased since then.

The comparatively low response rates for screening and uptake of oral glucose tolerance tests in white subjects have obviously led to an underestimate of the prevalence of undiagnosed diabetes in the community. Indeed, if the prevalence of diabetes in people invited for oral glucose tolerance tests but not attending was similar to that in those who attended, eight white and 17 Asian people had diabetes that remained undiagnosed. In addition, unless the group that refused initial screening was biased by an active decision of obese people or people with symptoms to avoid diagnosis, the total proportion of people with undiagnosed diabetes who were missed by our study would, because of their response rates, be $11 \%$ higher in Asians and $43 \%$ higher in white subjects, so that the disease remained undiagnosed in $40 \%$ of Asian diabetics and $42 \%$ of (predominantly female) white diabetics. We plan to follow up the people who were not screened, although all subjects previously diagnosed as diabetic should have been located. Many of those who did not attend for screening were reluctant to give any information or were absent on over 10 occasions. Information on long term nonresponders will be difficult to collect as about $20 \%$ of adults living in Foleshill leave the area every year. ${ }^{2}$

Our experience with the blood glucose concentrations of people who had negative results on oral glucose tolerance tests suggests that the screening method we used is unlikely to have missed many of those who had diabetes. Another possible explanation for the lower than expected number of people with undiagnosed diabetes is the fairly recent acceptance of the new criteria for the diagnosis of diabetes. These had been criticised for underdiagnosing diabetes and overdiagnosing impaired glucose tolerance. ${ }^{18}$ Even so, a large number of people with diabetes remain unidentified, particularly white people aged over 60 and Asians aged over 35 , and they would benefit from their diabetes being found and treated early. ${ }^{19}$ It may now be worth while for general practitioners systematically to screen these at risk groups to minimise future tissue damage and mortality.

We thank Coventry City Council's community programme team, the British Diabetic Association, Analox Ltd, Nordisk, Servier, Coventry and Warwickshire Hospital's biochemistry department, Beechams, Sherwood Medical, and Dr T D R Hockaday. DS is an Eli Lilly British Diabetic Association research fellow.

1 Mather HM, Keen $\mathrm{H}$. The Southall diabetes survey: prevalence of known diabetes in Asians and Europeans. Br Med f1985;291:1081-4.

2 Jarman B. Identification of underprivileged areas. Br Med f 1983;286:1705-9.

3 World Health Organisation. Diabetes mellitus. WHO Tech Rep Ser 1985; No 727.

4 Nie NH, Hull CH, Jenkins JG, Steinbrennev K, Bent DH. Statistical package for the social sciences (edition 2). New York: McGraw-Hill, 1986.

5 Office of Population Censuses and Surveys. Mid 1987 population estimates for Office of Population Censuses and Surveys. Mid 1987 population
England and Wales. OPCS Monitor 1988;No 1. (PP1 88/1.)

6 Armitage P. Statistical methods in medical research. Oxford: Blackwell Scientific, 1980:387.

7 Ahuja MMS. Epidemiological studies on diabetes mellitus in India. In: Ahuja MMS, ed. Epidemiology of diabetes in developing countries. New Delhi: Interprint, 1979:29-38.

8 Balarajan R, Bulusu L, Adelstein AM, Shuckla V. Patterns of mortality among migrants to England and Wales from the Indian subcontinent. $\mathrm{Br} M e d \mathcal{F}$ 1984;289:1185-7.

9 Neil HAW, Gatling W, Mather HM, et al. The Oxford community diabetes study: evidence for an increase in the prevalence of known diabetes in Great Britain. Diabetic Med 1987;4:539-43. 

measurement of obesity in a community. Indian f.Med Res 1984;80:365-71. $1 \mathrm{Keen} \mathrm{H}$. What's in a name? IDDM/NIDDM, type 1/type 2. Diabetic Med 1986:3:11-2.

12 Barker DJP, Gardner MJ, Power C. Incidence of diabetes amongst people aged 18-50 years in nine British towns: a collaborative study. Diabetologia 1982;22:421-5.

13 Mann JI, Lewis B, Shepherd J. Blood lipid concentrations and other cardiovascular risk factors: distribution, prevalence, and detection in Britain Br. Hed 1988;296:1702-6.

14 Multi-centre study. United Kingdom prospective diabetes study. IV. Characteristics of newly presenting type 2 diabetic patients: male preponderance and obesity at different ages. Diabetic Med 1988:5:154-9.

15 Multi-centre Study. United Kingdom prospective diabetes study. V. Charac- teristics of newly presenting type 2 diabetic patients: estimated insulin sensitivity and islet B-cell function Diabetic Med 1988;5:444-8.

16 Wilkerson HL, Krall LP. Diabetes in a New England town. JAMA 1947;135:209-16.

17 Sharp CL, Butterfield WJH, Keen H. Diabetes survey in Bedford 1962. Proc $R$ Soc Med 1964;57:193-202.

18 Massair V, Eschwege E, Valleron AJ. Imprecision of new criteria for the oral glucose tolerance test. Diabetologia 1983;24:100-6.

19 Hillson RM, Hockaday TDR, Newton DJ, Pim B. Delayed diagnosis of non insulin dependent diabetes is associated with greater metabolic and clinical abnormality. Diabetic Med 1985;2:383-6.

\title{
Adverse changes in mood and cognitive performance of house officers after night duty
}

\author{
D I Orton, J H Gruzelier
}

\begin{abstract}
The effects of long hours of work by junior doctors are the subject of growing concern. Experimental investigations of the effects of night duty on young doctors are few and have given inconclusive results. To measure the effects of long hours of work and reduced sleep on cognitive performance and mood 20 house officers ( 14 men and six women; mean age 25 , range 24-35) were examined for 35 minutes in one session towards the end of a normal working day and in a second session at the same time after working for up to 31 continuous hours with reduced sleep. The order of the sessions was counterbalanced across the subjects. Each session comprised a series of cognitive tests: choice reaction time, vigilance reaction time, and haptic sorting tests and completion of a profile of mood states and a general questionnaire. After night duty there was a significant slowing in cognitive processing together with a decline in reaction times in the vigilance test. Loss of sleep contributed only to increased variability in the choice reaction time. Significant deleterious changes in mood after night duty occurred in all the mood scales after night duty.
\end{abstract}

Continuous working may adversely affect the cognitive function and mood to the detriment of the welfare of doctors and their patients.

\section{Introduction}

There is growing concern about the desirability of junior doctors undertaking duty rosters that entail working continuously on consecutive days, typically with reduced sleep and sometimes with no sleep, that may occur twice a week or more. ${ }^{1}$ This practice has been said to encourage self reliance, affording both wider experience of clinical conditions and responsibilities and providing the necessary experience in dealing with emergencies under non-optimal conditions. Although these explanations seem valid, the risks to patients increase when errors are made by tired doctors, who lack agility in making decisions due to a slowing in cognitive functions. The personal lives of the doctors are compromised, which may lead to psychiatric problems, drug abuse, and broken marriages. ${ }^{2}$ Disillusion with hospital medicine may result, and undesirable behavioural traits that permeate future practice and lifestyle may develop..$^{2-4}$ These issues are becoming more pressing as demands grow owing to the exacting requirements of modern technology, as the number of malpractice suits increases, and as pressures mount to treat and discharge patients more quickly.
Proponents of busy night duty rosters have argued that impairment in function or mood may result from pre-existing inadequacies or reflect the natural doubts and insecurities of the novice doctor. ${ }^{5}$ Such viewpoints may be placed in better perspective if scientific investigations were to provide empirical evidence of the deleterious effects of long hours of work and loss of sleep in junior doctors. A review of existing studies shows that persuasive investigations to date have been few ${ }^{6}$ owing partly to the difficulty in undertaking occupational research of this type, which adds to the load of already tired and sometimes defensive doctors. ${ }^{7}$ We report on a study of cognitive and mood changes in 20 junior doctors at Charing Cross Hospital, all of whom were in their second house job.

\section{Subjects and methods}

We studied 20 preregistration house officers ( 14 men and six women; mean age 25 , range $24-35$ ). On average they had spent 6.75 months as house officers. Fourteen were house officers in general medicine and six were in general surgery. The subjects acted as their own controls and were tested twice, once in the midafternoon towards the end of a conventional working day that began at about 830 am and once at a similar time after they had been on duty throughout the preceding night and had started work at the usual time on the following day. Before testing the subjects were assigned randomly to two groups; half were tested first after night duty and half after a normal working day. At least one week elapsed between the sessions to minimise carryover effects. The test session lasted about 35 minutes.

Cognitive tests included choice reaction time, vigilance reaction time, haptic sorting test, and profile of mood states and general questionnaires.

Choice reaction time - The subject watched a video screen (CMB computer) and pressed a key with one hand on presentation of a vertical bar and another with the other hand in response to a horizontal bar. The stimuli were presented in a randomised sequence, and the duration between the stimuli was terminated by the response; the maximum duration of the stimulus was 1.84 seconds. Ninety stimuli were presented and divided into three equal blocks for analysis. Mean (SD) correct reaction time, the number of errors, and the standard deviation of the mean reaction time (which has been shown to increase after sleep $\operatorname{loss}^{8}$ ) were recorded.

Vigilance reaction time-One hundred letters were presented on the screen in sequence with instructions to press a key on seeing the letter $x$ but only when it had 